\title{
BIAYA EKSTERNAL DAN INTERNALISASI LIMBAH PABRIK KELAPA SAWIT
}

\section{The External Cost and Internalization of Palm Oil Mill Effluent}

\author{
Rany Utami ${ }^{\mathrm{a}}$, Eka Intan Kumala Putri ${ }^{\mathrm{b}}$, Meti Ekayani ${ }^{\mathrm{b}}$ \\ ${ }^{a}$ Program Studi Ekonomi Sumberdaya dan Lingkungan, Sekolah Pascasarjana Institut Pertanian Bogor, Kampus \\ IPB Dramaga,Bogor16680-ranyutami@gmail.com \\ ${ }^{b}$ Departemen Ekonomi Sumberdaya dan Lingkungan, Fakultas Ekonomi Manajemen Institut Pertanian Bogor, \\ Kampus IPB Dramaga, Bogor 16680
}

\begin{abstract}
The product of waste water from the process of millers may cause externality. In order to prevent the externality, millers has to internalize it by developing an installation of waste water treatment. The current is not sufficient for treating whole waste from the CPO process, therefore, can generate externality and external costs to community. This study aims to estimate the external cost and propose three alternatives of alternative of internalizations. The result of the research shows that the external cost is 146,194,433 IDR/year. The alternative of internalization offered are; compensation cost payment, sludge pond recovery, and well development.
\end{abstract}

Keywords: external costs, externalities, internalize, water waste, oil palm.

(Diterima: 25-04-2017; Disetujui: 19-09-2017)

\section{Pendahuluan}

\subsection{Latar Belakang}

Prospek cerah industri kelapa sawit telah menyebabkan perkebunan kelapa sawit mengalami perkembangan yang cepat. Perkembangan perkebunan kelapa sawit akan membuka peluang pengembangan industri, salah satunya pabrik kelapa sawit (PKS). Pengaruh keberadaan PKS dapat menghasilkan eksternalitas. Fisher (1996) mengatakan bahwa eksternalitas terjadi bila satu aktivitas pelaku ekonomi (baik produksi maupun konsumsi) mempengaruhi kesejahteraan pelaku ekonomi lain dan peristiwa yang ada terjadi di luar mekanisme pasar. Hufschmids et al. (1987) mengemukakan bahwa dampak yang ditimbulkan oleh industri terhadap lingkungan disebut dengan dampak eksternal. Dampak eksternal timbul bila fungsi kegunaan (manfaat) atau produksi seseorang tergantung pada kegiatan orang lain. Eksternalitas muncul bila dampak terhadap lingkungan yang mengakibatkan biaya dan manfaat sosial tidak dipertimbangkan oleh orang atau sekelompok orang yang mengakibatkan dampak tersebut. Aktivitas PKS dapat menimbulkan eksternalitas berupa limbah cair. Limbah tersebut terdiri dari tiga jenis, yaitu 1) kondenset steriliser, yaitu limbah yang mengandung kotoran dan lumpur dari minyak sebesar 0,9 ton per ton minyak yang dihasilkan, 2) limbah hidrosiklon dari pengolahan kernel sebesar 0.1-0.2 ton per ton minyak yang dihasilkan, dan 3) separator lumpur sebesar 1.5 ton per ton minyak yang dihasilkan, total volume limbah minyak kelapa sawit sebesar 2.5 ton per ton (Rahim, 1991). Limbah-limbah tersebut apabila tidak diolah dengan baik akan terbuang ke aliran sungai dan dapat mencemari air, sehingga menimbulkan eksternalitas bagi masyarakat. Namun eksternalitas yang ditimbulkan dari aktivitas tersebut seringkali diabaikan dan tidak diperhitungkan dalam komponen biaya suatu kegiatan (Hufschmids, 1992; Prasetia et al., 2016). Pabrik sebagai penghasil limbah umumnya tidak memperhitungkan biaya yang diakibatkan eksternalitas di dalam kebijakan Pabrik, biaya inilah yang dikenal sebagai biaya eksternal. Biaya eksternal merupakan biaya yang ditanggung masyarakat dan lingkungan yang tidak dimasukkan ke dalam perhitungan baik oleh produsen maupun konsumen (Kovacevic et al., 2001). Oleh sebab itu, untuk mengkompensasi eksernalitas yang timbul maka PKS seharusnya melakukan internalisasi.

Salah satu kasus eksternalitas negatif dari limbah pabrik kelapa sawit diduga terjadi akibat aktivitas PKS (PT X) di Provinsi Jambi, untuk mengatasi eksternalitas tersebut PKS PT X telah melakukan internalisasi dengan membuat instalasi pengolahan air limbah (IPAL). Seiring berjalannya waktu kondisi IPAL saat ini tidak mampu menampung limbah cair dari aktivitas PKS sehingga apabila intensitas hujan tinggi dan volume produksi tandan buah segar (TBS) meningkat, limbah cair tersebut dapat meluap dan terbuang ke sungai yang berada di wilayah Pabrik, akibatnya kembali terjadi eksternalitas akibat terbuangnya limbah cair dari IPAL.

Berdasarkan data Badan Lingkungan Hidup Daerah Kabupaten Tanjung Jabung Barat (2016) terdapat tiga parameter dari hasil uji air sungai yang berada di kawasan PKS PT X yang berada di atas baku mutu lingkungan (PP No.82/2001), yaitu florida (F), besi $(\mathrm{Fe})$, dan mangan (Mn). Menurunnya kualitas air sungai ini menyebabkan air sungai tercemar, sehingga 
pemanfaatan sungai oleh masyarakat mengalami penurunan. Untuk dapat memenuhi kebutuhan air sehari-hari, masyarakat harus mengganti konsumsi air yang awalnya berasal dari sungai ke sumber air lainya. PKS sebagai penghasil limbah harus dapat mengurangi dampak pencemaran tersebut dengan cara mencari alternatif internalisasi akibat eksternalitas. Internalisasi eksternalitas adalah memasukkan eksternalitas negatif atau biaya eksternal menjadi biaya produksi yang sebenarnya (Agustini, 2015).

\subsection{Tujuan Penelitian}

Berdasarkan hal tersebut, penelitian ini bertujuan untuk mengestimasi biaya eksternal yang timbul dari aktifitas IPAL PT $\mathrm{X}$ dan memberikan tiga alternatif untuk internalisasi eksternalitas negatif.

\section{Metode Penelitian}

\subsection{Lokasi dan Waktu Penelitian}

Penelitian ini dilakukan di Desa Penyabungan Kecamatan Merlung Kabupaten Tanjung Jabung Barat Provinsi Jambi pada bulan Juli-Agustus 2016.

\subsection{Metode Pengumpulan dan Analisis Data}

Responden dalam penelitian ini adalah masyarakat yang mengalami kerugian akibat eksternalitas limbah kelapa sawit dari IPAL, pengambilan sampel dilakukan secara sengaja (purposive). Jumlah responden sebanyak 75 rumah tangga (KK). Pengambilan data terhadap responden dilakukan dengan wawancara menggunakan kuesioner. Estimasi biaya eksternal dilakukan dengan pendekatan biaya pengganti air dan biaya berobat. Untuk mengestimasi besarnya internalisasi dilakukan menggunakan metode analisis contingent valuation method (CVM), analisis biaya produksi (perbaikan kolam IPAL), dan biaya investasi (pembuatan sumur galian).

\subsubsection{Estimasi Biaya Eksternal}

\section{a. Biaya Pengganti Air}

Untuk mengetahui nilai kerugian yang ditanggung masyarakat akibat mengganti sumber airnya menggunakan pendekatan biaya pengganti air. Nilai kerugian masyarakat diestimasi melalui biaya yang harus dikeluarkan oleh rumah tangga untuk dapat memenuhi kebutuhan air bersih untuk dikonsumsi. Berikut formulasi untuk mengestimasi biaya pengganti air (KLH, 2012).

$$
\begin{aligned}
& \mathrm{RBP}=\frac{\sum_{i=1}^{n} \mathrm{BPi}}{n} \\
& \mathrm{TBP}=\mathrm{RBP} \times \mathrm{N}
\end{aligned}
$$

Keterangan:

RBP : Rata-rata biaya pengganti responden (Rp/KK/tahun)
$\mathrm{BPi}$ : Biaya pengganti air responden ke-i (Rp/tahun)

$n \quad$ : Jumlah responden yang mengganti air

i : Responden ke-i $(1,2,3, . ., n)$

TBP : Total biaya pengganti air (Rp/tahun)

$\mathrm{N} \quad$ : Total populasi yang terkena dampak (KK)

\section{b. Biaya Berobat}

Selain biaya kerugian untuk mengganti air, dampak dari tercemarnya sungai dapat menggangu kesehatan masyarakat seperti gatal-gatal dan diare. Gangguan kesehatan akan menimbulkan kerugian, karena masyarakat harus mengeluarkan biaya tambahan untuk berobat. Untuk mengetahui besarnya biaya kesehatan yang harus dikeluarkan oleh rumah tangga diestimasi dengan pendekatan biaya berobat. Berikut formulasi untuk mengestimasi biaya berobat (KLH, 2012).

$$
\begin{aligned}
& \mathrm{RBB}=\frac{\sum_{i=1}^{n} \mathrm{BBi}}{n} \\
& \mathrm{TBB}=\mathrm{RBB} \times \mathrm{N}
\end{aligned}
$$

Keterangan:

$\begin{array}{ll}\mathrm{RBB} & : \begin{array}{c}\text { Rata-rata biaya berobat responden } \\ (\mathrm{Rp} / \mathrm{KK} / \mathrm{tahun})\end{array} \\ \mathrm{BBi} & : \text { Biaya berobat responden ke-i (Rp/tahun) } \\ n & : \text { Jumlah responden yang berobat } \\ \mathrm{i} & : \text { Responden ke-i }(1,2,3, \ldots, \mathrm{n}) \\ \mathrm{TBB} & : \text { Total biaya berobat }(\mathrm{Rp} / \mathrm{tahun}) \\ \mathrm{N} & : \text { Populasi yang terkena dampak }(\mathrm{KK})\end{array}$

\subsubsection{Estimasi Alternatif Internalisasi}

\section{a. Kompensasi dengan CVM}

Estimasi besarnya biaya pengganti kerugian akibat limbah minyak kelapa sawit dianalisis menggunakan pendekatan CVM (Contingent Valuation Method). CVM adalah metode teknik survey untuk menanyakan kepada masyarakat mengenai nilai atau harga yang mereka berikan terhadap komoditi yang tidak memiliki pasar seperti barang lingkungan (Yakin, 1997). Menurut Pearce et al (2006) dalam Fauzi (2015) secara umum analisis CVM melibatkan tiga tahap utama, yaitu 1) identifikasi barang dan jasa yang akan dievaluasi, 2) konstruksi skenario hipotetik, dan 3) memperoleh informasi kesanggupan menerima biaya pengganti dengan menanyakan besarnya biaya pengganti melalui format tertentu. Tahapan penerapan CVM untuk menentukan nilai WTA (Hanley dan Spash, 1993) yaitu:

1. Membuat pasar hipotetik

Pasar hipotetis dibuat dengan menggunakan skenario bahwa PKS yang melakukan kegiatan pengolahan kelapa sawit akan memberlakukan pengganti biaya kerugian yang bertujuan untuk mengurangi kerugian akibat ekternalitas negatif yang timbul. Pertanyaan dalam pasar hipotetis adalah: bersediakah bapak/ibu berpartisipasi dalam kebijakan PKS untuk mengurangi eksternalitas dari limbah cair dari instalasi pengolahan air limbah (IPAL)?”

2. Memperoleh penawaran besarnya nilai WTA 
Metode yang dilakukan untuk memperoleh nilai WTA menggunakan metode dichotomous choice dengan teknik single bounded dichotomus choice. Metode ini digunakan karena relatif mudah dijawab oleh responden. Dalam dichotomous choice responden hanya diajukan pertanyaan dan cukup menjawab "ya" atau "tidak". Nilai rupiah yang ditawarkan disebut nilai penawaran (bid value) (Whitehead, 2006 dalam Fauzi, 2015). Setelah mendapat nilai penawaran WTA, dilakukan pengelompokan kepada 75 responden, di mana jumlah kelompok disesuaikan dengan jumlah kelas bid yang ditawarkan. Penentuan responden pada masing-masing kelas bid ditentukan secara random.

3. Memperkirakan nilai rata-rata WTA (EWTA) Nilai rataan WTA dapat diduga menggunakan model analisis logistik (SPSS) yaitu $\alpha$ (konstanta) dan $\delta$ (koefisien bid). Formulasi perhitungan EWTA:

$$
\begin{array}{ll}
\text { EWT } A & =-\frac{\alpha}{\delta} \\
\text { Keterangan: } & \\
\text { EWTA } & : \text { Nilai rata-rata WTA (Rp/tahun) } \\
\alpha & : \text { Konstanta } \\
\delta & \text { Koefisien bid }
\end{array}
$$

4. Mengagregatkan data

Penjumlahan data merupakan proses dimana nilai rata-rata sampel penawaran dikonversikan terhadap total populasi yang dimaksud, salah satu cara untuk mengkonversikan ini adalah mengkalikan rataan sampel dengan jumlah populasi. Rumus yang dapat digunakan adalah:

$$
T W T A=E W T A \times N
$$

\section{Keterangan:}

TWTA : Total WTA (Rp/tahun)

EWTA : Nilai rata-rata WTA (Rp/tahun)

$\mathrm{N} \quad$ : Populasi yang terkena dampak $(\mathrm{KK})$

\section{b. Biaya Pengaktifan Kembali IPAL}

Analisis biaya produksi digunakan untuk mengestimasi besarnya internalisasi dalam bentuk perbaikan kolam IPAL. Biaya dalam perbaikan kolam IPAL terdiri dari biaya penyusutan pengerukan kolam dan biaya operasional ketika kolam dapat digunakan kembali. Estimasi biaya penyusutan pengerukan kolam diperoleh dari studi sebelumnya (Fikri et al., 2016) sedangkan biaya operasional diperoleh dari rata-rata biaya operasional PKS PT X tiga tahun terakhir. Biaya penyusutan kolam merupakan biaya tetap yang harus dikeluarkan oleh Pabrik setiap tahun berdasarkan asumsi umur ekonomis yaitu 3 tahun, sedangkan untuk biaya operasional diestimasi dengan mengalikan besarnya volume dengan biaya operasional per $\mathrm{m}^{3}$. Formulasi analisis biaya produksi sebagai berikut (Soekartawi, 1995):

$\mathrm{TC}=\mathrm{FC}+\mathrm{VC}$

Keterangan:

TC: Total biaya pengaktifan kolam IPAL (Rp/tahun)

FC: Biaya pengerukkan kolam (Rp/tahun)

VC: Biaya operasional IPAL (Rp/tahun)

\section{c. Biaya Pembuatan Sumur Baru}

Untuk biaya pembuatan sumur galian menggunakan biaya investasi awal dibagi dengan umur ekonomis sumur. Formulasi analisis biaya penyusutan menggunakan rumus :

$\mathrm{D}=\mathrm{Nb}: \mathrm{U}$

Keterangan:

$\begin{array}{ll}\mathrm{D} & \text { : Biaya pembuatan sumur (rupiah/tahun) } \\ \mathrm{Nb} & \text { : Nilai baru (investasi) (rupiah) } \\ \mathrm{U} & \text { : Umur ekonomis (tahun) }\end{array}$

\section{Hasil dan Pembahasan}

\subsection{Gambaran Umum Instalasi Pengolahan Air Limbah (IPAL) PTX}

PKS PT X memiliki kapasitas produksi TBS sebesar 60 ton/jam. Hasil pengolahan minyak kelapa sawit menghasilkan buangan berupa limbah. Limbah padat yang dihasilkan dari proses produksi minyak kelapa sawit yaitu $23 \%$ berupa tandan kosong, 6,5\% cangkang, $4 \%$ wet decanter solid (seperti tanah liat), dan $13 \%$ berupa serabut (fiber) sedangkan limbah cair sebesar $50 \%$. Limbah cair yang dihasilkan berasal dari proses perebusan, pemisahan minyak, proses pembersihan alat dan proses produksi. IPAL yang dimiliki PKS PT X menggunakan sistem kolam (ponding system) dimana terdapat sembilan unit kolam limbah.

Pengolahan limbah cair yang dilakukan di PT X memanfaatkan bakteri anaerob dan aerob yang dikembangbiakan di setiap kolam limbah. Proses penguraian limbah kelapa sawit berlangsung dalam kondisi anaerob, setelah itu dilanjutkan dalam kondisi aerob. Proses aerob merupakan penguraian oleh bakteri aerob yang dibantu oleh aerator, setelahnya terjadi proses pengendapan yang berfungsi untuk mengurangi padatan (Lubis et al., 2011). Pemanfaatan menggunakan bakteri anaerob dan aerob ini dilakukan agar pengolahan limbah yang dilakukan dapat menghasilkan pupuk cair yang dapat digunakan dan didistribusikan ke kebun-kebun kelapa sawit milik Pabrik dengan menggunakan land application. 


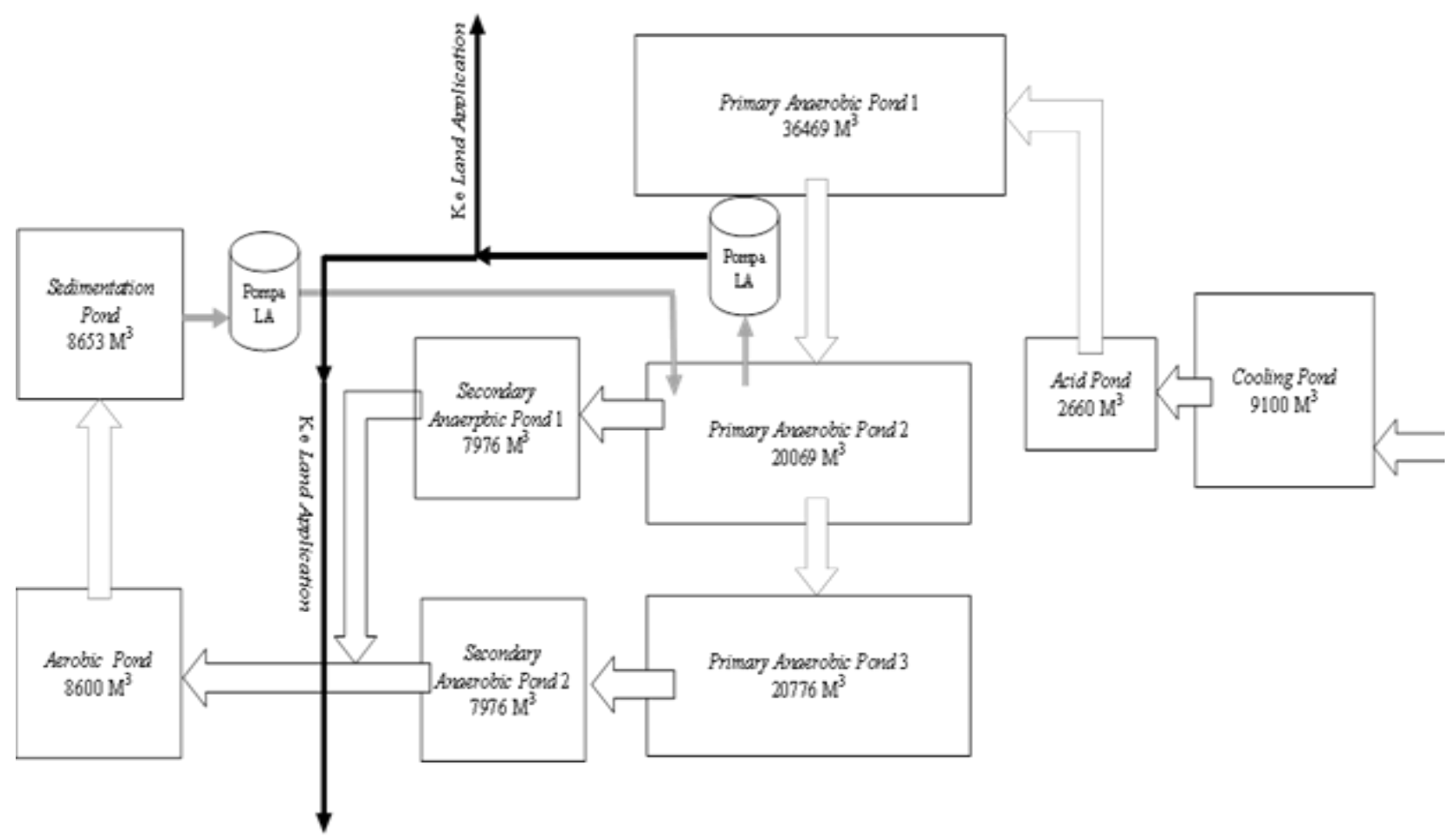

Gambar 1. Layout IPAL PKS PT X

\subsection{Eksternalitas Akibat Limbah Cair dari Instalasi Pengolahan Air Limbah (IPAL)}

PKS PT X telah melakukan internalisasi dalam bentuk pembuatan IPAL, namun seiring berjalannya waktu kondisi IPAL saat ini tidak mampu menampung limbah cair dari aktivitas Pabrik sehingga apabila intensitas hujan tinggi dan volume produksi TBS sedang meningkat, limbah cair dari kolam IPAL akan meluap dan terbuang ke sungai di Desa Penyabungan, akibatnya limbah cair tersebut kembali menimbulkan eksternalitas.

Limbah cair kelapa sawit merupakan sumber pencemar pontensial yang dapat memberikan dampak serius bagi lingkungan (Mahajoeno et al., 2008). Pembuangan limbah cair industri berkontribusi besar terhadap kontaminasi air sungai (Islam et al. 2010; Chaurasia et al. 2011). Akibat limbah cair tersebut, air sungai di Desa Penyabungan tercemar. Terkontaminasi atau tercemarnya air sungai dapat menyebabkan perubahan $\mathrm{pH}$, pengurangan kandungan oksigen dan menyebabkan tekanan osmotik yang tinggi (Raja et al., 2008; Chaurasia et al., 2011). Izah et al. (2016) mengevaluasi mengenai dampak lingkungan dari pengolahan kelapa sawit, di mana limbah yang dihasilkan dari pengolahan tersebut cukup besar, limbah cair yang dihasilkan dalam pengolahan minyak kelapa sawit dapat mencemari ekosistem perairan, selain itu limbah cair yang masuk ke tanah akan meningkatkan $\mathrm{pH}$ tanah menjadi lebih asam dan meningkatkan komposisi hara dalam tanah seperti nitrogen, kalium, fosfor, dan lainnya. Hal ini tentu akan menggangu kualitas air bersih dan kesehatan bagi masyarakat apabila terus mengkonsumsi air yang terkena limbah.
Studi lain dilakukan oleh Rupani et al. (2010) di antara limbah yang dihasilkan oleh pabrik kelapa sawit, POME (palm oil mill effluent) dianggap limbah yang paling berbahaya terhadap lingkungan jika dibuang tanpa diolah terlebih dahulu. Limbah cair kelapa sawit tersebut berupa cairan kecoklatan yang sangat pekat yang mengandung minyak/lemak, COD dan BOD yang tinggi.

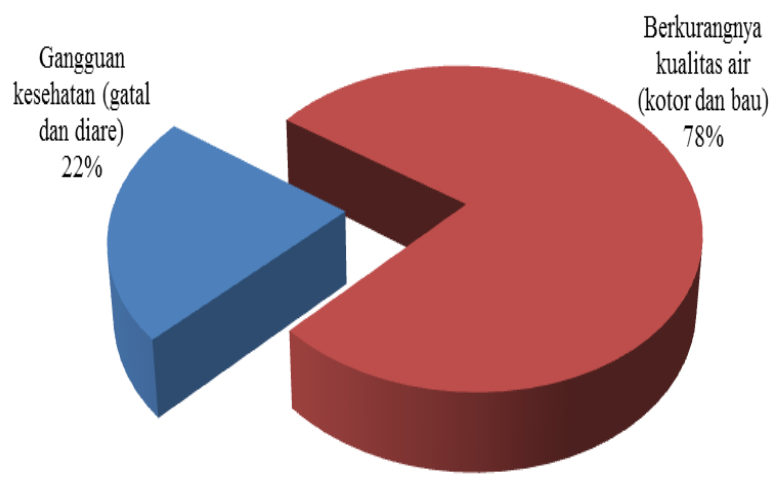

Gambar 2. Eksternalitas negatif yang dirasakan masyarakat Desa Penyabungan

Berdasarkan Gambar 2, eksternalitas negatif yang dirasakan oleh masyarakat berbeda-beda. Sebanyak 78 persen mengatakan perubahan yang terjadinya berubahnya kualitas air sungai, kondisi ini mengakibatkan air sungai menjadi kotor dan berbau sehingga pemanfaatan air sungai di Desa Penyabungan untuk konsumsi mulai berkurang. Studi mengenai dampak dari limbah industri terhadap kualitas air sungai telah di lakukan oleh Yadav et al. (2011), dalam studinya di sungai Kosi Kabupaten Rampu (India) menunjukkan pada parameter fisio-kimia air sungai berada di atas batas yang diizinkan, sehingga air sungai tersebut tidak 
layak untuk dikonsumsi, keperluan sehari-hari dan irigasi. Studi lain oleh Chaurasia et al. (2011) menyatakan dimana pembuangan limbah cair industri yang dilakukan secara terus menerus dapat menyebabkan akumulasi kontaminan yang parah, hal ini dapat mempengaruhi kehidupan manusia dan hewan yang berada di sekitar sungai tersebut.

Sisanya sebanyak 22 persen mengalami gangguan kesehatan seperti diare dan gatal-gatal, hal ini karena masyarakat memanfaatkan air sungai untuk minum dan mandi. Sejalan dengan Halder et al. (2015) salah satu dampak langsung maupun tidak langsung dari limbah cair yang mencemari air sungai dapat mengakibatkan masalah kesehatan, masalah kesehatan antara lain masalah kulit, hal ini mungkin saja terjadi akibat $\mathrm{pH}$ air yang tinggi yang dapat mengakibatkan iritasi kulit dan gatal-gatal., sedangakan untuk masalah diare, hal ini bisa terjadi akibat air sungai sudah terkontaminasi mikroba yang berasal dari limbah cair.

\subsubsection{Estimasi Biaya Pengganti Air}

Bagi masyarakat di Desa Penyabungan, air sungai merupakan sumber air utama untuk kebutuhan seharihari. Kegiatan yang dapat dilakukan di aliran sungai seperti mencuci, mandi, MCK, memasak bahkan untuk minum. Namun, setelah adanya limbah minyak kelapa sawit, kondisi dan kualitas air sungai sudah menurun. Saat ini pemanfaatan air sungai sudah mulai terbatasi, meskipun masih ada sebagian yang mengkonsumsinya namun sebagian besar air sungai sudah tidak di konsumsi namun pemakaiannya untuk non konsumsi. Sebanyak 25,33\% masih memanfaatkan air sungai untuk dikonsumsi, sedangkan $74,67 \%$ dari total responden telah mengganti konsumsi dari air sungai ke sumber air lainnya, hal ini menunjukkan berkurangnya penggunaan air sungai oleh masyarakat di Desa Penyabungan. Sejalan dengan Soemirat (2001), berkurangnya masyarakat yang menggunakan air sungai untuk dikonsumsi dikarenakan kualitas sungai saat ini sudah menurun, hal ini karena jumlah zat padat terlarut dalam air sungai bertambah, akibatnya kesadahan air akan naik, dan akhirnya berdampak pada kesehatan. Sumber air yang digunakan oleh masyarakat Desa Penyabungan sebagai pengganti air sungai berasal dari air sumur dan membeli air isi ulang.

Tindakan yang dilakukan oleh responden untuk mengganti sumber air bersih dengan membeli air isi ulang dan membuat sumur, akan menyebabkan responden mengeluarkan biaya tambahan atau biaya pengganti setiap bulannya. Total biaya kerugian akibat mengganti sumber air di Desa Penyabungan sebesar Rp 134.526.933/tahun. Sebagian besar masyarakat di Desa penyabungan menggunakan air sumur sebagai pengganti sumber air (Tabel 1), hal ini dilakukan karena dengan membuat sumur akan lebih efektif meskipun untuk membuat sumur biaya yang dikeluarkan akan lebih besar dibandingkan dengan membeli air galon, namun pemanfaatan dengan air sumur lebih banyak selain untuk minum dapat digunakan untuk memasak, mandi, dan mencuci sedangkan air galon hanya dapat dimanfaatkan untuk minum dan masak.

\subsubsection{Estimasi Biaya berobat}

Dampak lain yang dialami masyarakat akibat limbah adalah gangguan kesehatan. Air limbah dapat mengandung bibit penyakit yang menimbulkan penyakit bawaan air (waterborne disease) yang dapat menimbulkan gangguan kesehatan bagi makhluk hidup yang mengkonsumsinya (Sumantri dan Arif, 2010). Sebanyak $21 \%$ dari total responden mengalami gangguan kesehatan akibat air sungai yang tercemar. Gangguan kesehatan yang dialami masyarakat yaitu gatal-gatal dan diare. Kulit menjadi gatal-gatal merupakan respon kulit terhadap faktor luar yang menggangu, respon tersebut biasanya berhubugan dengan alergi (Djuanda, 2002), hal ini karena sungai yang dimanfaatkan oleh masyarakat telah mengalami pencemaran. Selain itu, penyakit yang sering dialami masyarakat adalah diare atau gangguan pencernaan. Tjay dan Raharja (2007) diare dapat disebabkan karena bertumpuknya cairan di dalam usus karena terganggunya resopsi air. Diare dapat bersumber dari mikroorganisme yang merugikan sepert E.Coli, Shigella, Salmonella dan Campylobacter yang terkontaminasi pada air yang digunakan.

Masyarakat yang mengalami gangguan kesehatan, akan membutuhkan biaya tambahan untuk berobat. Biaya berobat inilah yang menjadi biaya eksternal. Kerugian di Desa Penyabungan untuk biaya berobat sebesar Rp 11,667,500/tahun (Tabel 1). Total kerugian akibat eksternalitas yang terjadi di Desa Penyabungan untuk mengganti biaya air bersih dan biaya berobat sebesar Rp 146,194,433/tahun (Tabel 1). Besarnya nilai kerugian ini terasa berat karena harus ditanggung oleh masyarakat. Akibat eksternalitas tersebut, Pabrik perlu melakukan internalisasi untuk mengurangi kerugian yang ditanggung oleh masyarakat.

\subsection{Internalisasi eksternalitas akibat limbah cair dari IPAL}

Internalisasi eksternalitas yang ditawarkan dalam penelitan ini akibat limbah yang berasal dari kolam penampungan instalasi pengolahan air limbah (IPAL) dapat dilakukan dengan beberapa cara, antara lain pemberian biaya pengganti atas kerugian yang dirasakan masyarakat, melakukan perbaikan kolam IPAL, dan membuat sumur galian sebagai pengganti sumber air bersih. 
Tabel 1. Estimasi biaya eksternal masyarakat Desa Penyabungan (rupiah/tahun)

\begin{tabular}{|c|c|c|c|c|c|}
\hline Komponen & $\begin{array}{c}\text { Jumlah } \\
\text { responden }(\mathrm{KK})\end{array}$ & $\begin{array}{c}\text { Persentase } \\
\text { responden }(\%)\end{array}$ & $\begin{array}{c}\text { Populasi } \\
\text { masyarakat } \\
(\mathrm{KK})^{*}\end{array}$ & $\begin{array}{c}\text { Biaya rata-rata } \\
\text { (rupiah/KK/tahun) }\end{array}$ & $\begin{array}{c}\text { Biaya kerugian } \\
\text { (rupiah/tahun) }\end{array}$ \\
\hline \multicolumn{6}{|l|}{ A. Biaya pengganti air } \\
\hline Air isi ulang (galon) & 9 & 16.07 & 35 & 506,667 & $17,733,333$ \\
\hline Air sumur & 29 & 51.79 & 111 & 518,520 & $57,555,720$ \\
\hline Air sumur + galon & 18 & 32.14 & 69 & 858,520 & $59,237,880$ \\
\hline Total biaya pengganti air & & & & & $134,526,933$ \\
\hline \multicolumn{6}{|l|}{ B. Biaya berobat } \\
\hline Diare & 5 & 31.25 & 19 & 220,000 & $4,180,000$ \\
\hline Gatal & 8 & 50,00 & 30 & 176,250 & $5,463,750$ \\
\hline Diare + gatal & 3 & 18.75 & 12 & 183,333 & $2,200.000$ \\
\hline Total biaya berobat & & & & & $11,667,500$ \\
\hline \multicolumn{6}{|l|}{ C. Total biaya eksternal } \\
\hline $\mathrm{A}+\mathrm{B}$ & & & & & $146,194,433$ \\
\hline
\end{tabular}

Keterangan : (*) jumlah populasi masyarakat (KK) diperoleh dari persentase responden dikali dengan total populasi yang mengalami kerugian akibat eksternalitas limbah kelapa sawit dari IPAL (total populasi masyarakat yang mengeluarkan biaya pengganti air $215 \mathrm{KK}$, dan total populasi masyarakat yang mengeluarkan biaya berobat $61 \mathrm{KK}$ )

\subsubsection{Estimasi biaya kompensasi}

Biaya kompensasi merupakan salah satu bentuk kebijakan yang dapat dilakukan oleh PKS sebagai internalisasi terhadap eksternalitas yang timbul akibat limbah cair. Berdasarkan survei menunjukan 100\% responden bersedia berpartisipasi dalam program PKS untuk mengurangi eksternalitas. Kesediaan responden untuk menerima biaya kompensasi sebesar Rp 60,000 sebanyak $76 \%$ dan $24 \%$ tidak bersedia menerima, untuk kategori kesediaan menerima biaya kompensasi sebesar Rp. 50,000 yang bersedia sebesar $60 \%$ dan yang tidak bersedia sebesar $40 \%$, sedangkan untuk biaya kompensasi sebesar Rp. 40,000 sebanyak 40\% bersedia menerima dan sisanya $60 \%$ tidak bersedia menerima. Berdasarkan hal tersebut, semakin besar biaya pengganti yang ditawarkan kepada masyarakat maka akan semakin besar kesediaan masyarakat untuk menerima biaya kompensasi. Berdasarkan perhitungan menggunakan model logit diperoleh EWTA sebesar Rp. $56,565 / \mathrm{KK} /$ bulan. Estimasi total biaya kompensasi yang diterima oleh masyarakat di Desa Penyabungan sebesar Rp. 154,082.748/tahun (Tabel 2).

Tabel 2. Estimasi Biaya Kompensasi Masyarakat Desa Penyabungan

\begin{tabular}{lr}
\hline Uraian & \multicolumn{1}{c}{ Jumlah } \\
\hline Populasi yang terkena dampak (KK) & 227 \\
Rata-rata WTA responden (Rp/KK/bulan) & 56.565 \\
Total WTA masyarakat (Rp/bulan) & 12.840 .229 \\
Total WTA masyarakat (Rp/tahun) & 154.082 .748 \\
\hline
\end{tabular}

Besarnya nilai manfaat internalisasi dari biaya pengganti sebesar Rp 154.082.748/tahun, besarnya nilai internalisasi ini jika diasumsikan relevan dalam kurun waktu 3 tahun ke depan, sehingga total biaya pengganti yang harus dikeluarkan oleh PKS selama 3 tahun sebesar Rp 462.248.244. Hal ini berdasarkan nilai penawaran (bid) yang diperoleh dari biaya pembuatan sumur dengan asumsi umur ekonomis/ketersediaan air sumur dapat dimanfaatkan selama 3 tahun tanpa adanya biaya perbaikan, perawatan, dan penggalian.

\subsubsection{Estimasi biaya pengaktifan kembali kolam IPAL}

Internalisasi untuk mengurangi kerugian akibat limbah cair selain memberi biaya kompensasi kepada masyarakat adalah dengan cara memperbaiki kolam instalasi pengolahan air limbah (IPAL) dan pembuatan sumur galian. Perbaikan kolam IPAL yang dilakukan adalah dengan mengeruk endapan lumpur di dua kolam yang sudah tidak digunakan yaitu primary anaerobic 3 sebesar 20,776 $\mathrm{m}^{3}$ dan secondary anaerobic 2 sebesar $7,976 \mathrm{~m}^{3}$, sehingga total volume IPAL yang akan dikeruk sebesar $28,752 \mathrm{~m}^{3}$. Estimasi biaya pengerukan kolam diperoleh dari literatur dari Fikri et al. (2016) yang dilakukan pada tahun 2014 yang sudah di compounding setara dengan tahun 2017 sebesar Rp. 70,298,777. Hasil perhitungan diperoleh biaya operasional sebesar Rp. $1,215 / \mathrm{m}^{3}$ sehingga total biaya operasional untuk volume $28,752 \mathrm{~m}^{3}$ sebesar Rp. 34,926,394/tahun. Total biaya produksi dari perbaikan kolam IPAL PKS PT X sebesar Rp. 105,225,171 (Tabel 4).

\subsubsection{Estimasi pembuatan sumur galian baru}

Estimasi biaya untuk pembuatan sumur diperoleh dari data primer di lapangan, berdasarkan hasil wawancara rata-rata biaya pembuatan sumur sebesar Rp. 7,000,000. Saat ini, di Desa Penyabungan terdapat kurang lebih 43 sumur, namun jumlah sumur tersebut belum bisa memenuhi kebutuhan air bersih untuk seluruh masyarakat di Desa Penyabungan. Satu buah sumur dapat digunakan untuk tiga KK, sehingga dari $288 \mathrm{KK}$ jumlah ideal sumur untuk bisa memenuhi kebutuhan air bersih seluruh masyarakat sebanyak 96 buah, dengan demikian kebutuhan sumur yang perlu dibuat sebanyak 53 buah. Berdasarkan hasil perhitungan total biaya pembuatan sumur di Desa Penyabungan dengan asumsi umur ekonomis sumur selama 3 tahun sebesar Rp. $123,666,667 /$ tahun

Untuk mengetahui manfaat dari tiga alternatif yang ditawarkan, dilakukan perbandingan besarnya biaya yang dikeluarkan PKS PT X dalam kurun waktu 3 tahun. berdasarkan Tabel 5, dari ketiga alternatif internalisasi yang ditawarkan internalisasi yang paling besar dalam tiga tahun ke depan adalah biaya kompensasi sebesar Rp. 421,578,942, selanjutnya biaya pembuatan sumur galian sebesar Rp. 338,358,857 dan yang terakhir adalah biaya pengaktifan IPAL sebesar Rp. $162,828,746$. 


\begin{tabular}{|c|c|}
\hline $\begin{array}{ll}\text { Komponen } \\
\end{array}$ & Nilai \\
\hline \multicolumn{2}{|l|}{ 1. Perbaikan Kolam IPAL } \\
\hline \multicolumn{2}{|l|}{ A. Biaya pengerukkan kolam } \\
\hline Volume kolam yang diperbaiki $\left(\mathrm{m}^{3}\right)$ & 28,752 \\
\hline Biaya pengerukan $\left(\mathrm{Rp} / \mathrm{m}^{3}\right)$ & 2,445 \\
\hline Total biaya pengerukan (Rp) & $70,298,777$ \\
\hline \multicolumn{2}{|l|}{ B. Biaya operasional } \\
\hline Biaya operasional IPAL $\left(\mathrm{Rp} / \mathrm{m}^{3} / \mathrm{thn}\right)$ & 1,215 \\
\hline Total biaya operasional (Rp/thn) & $34,926,394$ \\
\hline C. Total biaya perbaikan kolam IPAL (Rp) & $105,225,171$ \\
\hline \multicolumn{2}{|l|}{ 2. Pembuatan Sumur Galian } \\
\hline Biaya investasi (Rp) & $7,000,000$ \\
\hline Jumlah sumur (buah) & 53 \\
\hline Biaya Penyusutan sumur (Rp) & $371,000,000$ \\
\hline Umur ekonomis sumur (thn) & 3 \\
\hline Total biaya pembuatan sumur (Rp/thn) & $123,666,667$ \\
\hline
\end{tabular}

Tabel 5. Present Value dari Alternatif Internalisasi yang Ditawarkan

\begin{tabular}{|c|c|c|c|c|}
\hline \multirow{2}{*}{ Biaya } & \multicolumn{3}{|c|}{ Tahun $(t)$} & \multirow{2}{*}{ Total Present Value } \\
\hline & 2017 & 2018 & 2019 & \\
\hline Biaya Eksternal & $146,194,433$ & $146,194,433$ & 146.194 .433 & \\
\hline Present Value (PV) Biaya Eksternal & $139,565,091$ & $133,236,364$ & 127.194.620 & 399.996 .075 \\
\hline \multicolumn{5}{|l|}{ Alternatif Internalisasi } \\
\hline Kompensasi & $154,082,748$ & $154,082,748$ & 154.082 .748 & \\
\hline Pengaktifan IPAL & $105,225,171$ & $34,926,394$ & 34.926 .394 & \\
\hline Pembuatan sumur galian & $123,666,667$ & $123,666,667$ & 123.666 .667 & \\
\hline \multicolumn{5}{|l|}{ PV Alternatif Internalisasi } \\
\hline PV Kompensasi & $147,095,702$ & $140,425,491$ & 134.057 .748 & 421.578 .942 \\
\hline PV Pengaktifan IPAL & $100,453,624$ & $31,830,663$ & 30.544 .458 & 162.828 .746 \\
\hline PV Pembuatan sumur galian & $118,058,870$ & $112,705,365$ & 107.594.621 & 338.358 .857 \\
\hline
\end{tabular}

Ket : BI rate pada tahun 2017 sebesar 4,75\%

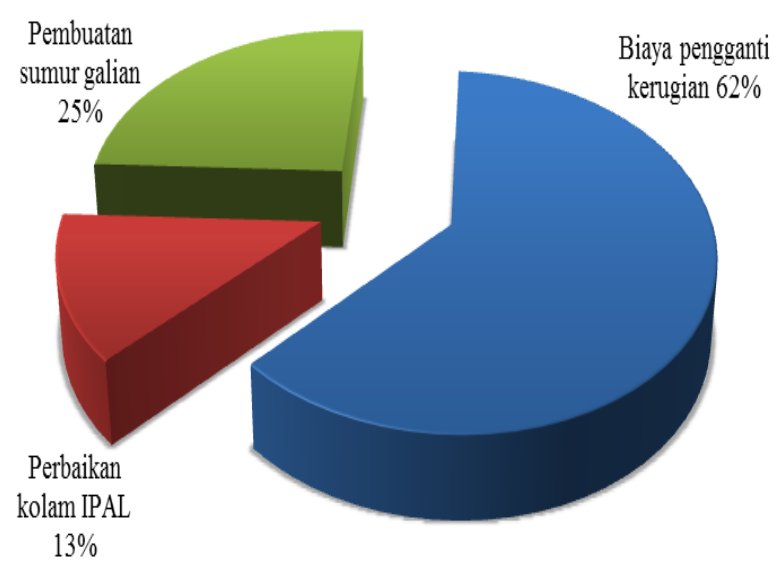

Gambar 3. Internalisasi eksternalitas yang diharapkan masyarakat Desa Penyabungan

Berdasarkan Gambar 3, sebesar $62 \%$ bentuk internalisasi yang diharapkan oleh masyarakat adalah pemberian biaya kompensasi. Hal ini karena manfaat dari biaya kompensasi diterima langsung oleh masyarakat, sehingga manfaat yang diperoleh dapat digunakan untuk mengurangi biaya eksternal. Namun, internalisasi ini tidak dapat mengurangi pencemaran yang terjadi sehingga eksternalitas masih dirasakan oleh masyarakat. Internalisasi berikutnya yang diharapkan oleh masyarakat adalah pembuatan sumur galian sebesar $25 \%$. Pembuatan sumur galian dilakukan sebagai alternatif pengganti sumber air bersih, karena masyarakat tidak dapat menggunakan sungai yang telah tercemar, internalisasi ini dapat menjadi solusi masyarakat dalam memperoleh pasokan air bersih. Namun seperti halnya biaya kompensasi, internalisasi ini tidak menyelesaikan permasalahan pencemaran. Sehingga dikhawatirkan pencemaran akan tetap terjadi bahkan semakin parah apabila tidak ditanggulangi, selain itu alternatif ini mengharuskan masyarakat mengeluarkan biaya tambahan seperti biaya listrik, perawatan, dll.

Internalisasi lainnya yang dapat dilakukan adalah perbaikan kolam IPAL, sebesar $13 \%$ responden berharap internalisasi yang dapat dilakukan. Internalisasi ini menjadi internalisasi yang direkomendasikan. Hal ini karena, biaya yang harus ditanggung PKS lebih kecil dibandingkan dengan internalisasi yang lain. Meskipun biaya ganti rugi ini tidak diterima langsung oleh masyarakat dan pengelolaan sepenuhnya dilakukan oleh pihak Pabrik, sehingga masyarakat tidak dapat memonitoring kegiatan pengolahan limbah tersebut, namun keuntungan dari internalisasi ini adalah tidak ada lagi limbah yang terbuang ke aliran sungai, sehingga permasalahan pencemaran limbah dapat teratasi dan terselesaikan. Berdasarkan penelitian ini, pengaktifan IPAL menjadi alternatif yang dianggap paling efisien.

\section{Kesimpulan}

PKS PT X telah IPAL namun masih ada limbah cair yang terbuang ke aliran sungai yang menimbulkan biaya eksternal. Total biaya eksternal akibat eksternalitas sebesar Rp 146.194.433/tahun. Studi ini menawarkan tiga alternatif internalisasi yaitu pemberian dana kompensasi, pengaktifan kembali kolam IPAL, dan pembuatan sumur galian baru. Interalisasi yang paling efisien adalah pengaktifan kembali kolam IPAL karena biaya yang dikeluarkan lebih kecil dan masalah pencemaran dapat teratasi. 


\section{Ucapan Terima Kasih}

Ucapan terima kasih disampaikan kepada pihak Lembaga Pengelola Dana Pendidikan (LPDP) sebagai pemberi dana beasiswa tesis untuk membiayai penelitian ini.

\section{Daftar Pustaka}

[1] Agustini., 2015. Internalisasi Eksternalitas PLTU Batubara. Jurnal M\&E. 13(2), pp. 61-75.

[2] [BLHD] Badan Lingkungan Hidup Daerah Tanjung Jabung Barat, 2016. Laporan Hasil Uji Air Sungai. Tidak Diterbitkan.

[3] Chaurasia, N.K., R.K. Tiwari, 2011. Effect of Industrial Effluents and Wastes on Physico-Chemical Parameters of River Rapti. Advances in Applied Science Research. 2(5), pp. 207-211.

[4] Djuanda, A., 2002. Ilmu Penyakit Kulit dan Kelamin. FK UI, Jakarta.

[5] Fauzi, A., 2015. Valuasi Ekonomi dan Penilaian Kerusakan Sumberdaya alam dan Lingkungan. IPB Press, Bogor.

[6] Fikri, Z.A., B. Rahmawati, N. Paryati, 2016. Analisis Kapasitas Produksi Excavator pada Proyek Perumahan Pertamina Cibubur. Jurnal Teoritis dan Terapan Bidang Rekayasa Sipil. 4(1), pp. 57-67.

[7] Fisher, R.C., 1996. State and Local Public Finance. Irwin, New York.

[8] Halder, J.N., M.N. Islam, 2015. Water Pollution and its Impact on the Human Health. Journal of Environment and Human. 2(1), pp. 36-46.

[9] Hanley, N., C.L. Spash, 1993. Cost-Benefit Analysis and Environmental. England: Edward Elger Publishing Limited.

[10] Hufschmids, M.M., D.E. James., A.D. Meister., B.T. Bower., J. Dixon, 1987. Lingkungan Sistem Alami dan Pembangunan: Pedoman Penilaian Ekonomis. Reksohadiprojo S, penerjemah. Gajahmada University Press, Yogyakarta.

[11] Izah, S.C., T.C.N. Angaye, E.I. Ohimain., 2016. Environmental Impacts of Oil Palm Processing in Nigeria. Biotechnol Res. 2(3), pp. 132-141.

[12] [KLH] Kementrian Lingkungan Hidup, 2012. Panduan Valuasi Ekonomi Ekosistem Hutan, Indonesia.
[13] Kovacevic, T., Z. Tomsic., N. Debrecin, 2001. External Cost of Electricity, $18^{\text {th }}$ Congress of World Energy Council, Buenos Aires.

[14] Lubis, R.E., A. Widanarko, 2011. Buku PintarKelapa Sawit. Agro Media Pustaka, Jakarta.

[15] Mahajoeno, E., B.W. Lay., S.H. Sutjahjo., Siswanto, 2008. Potensi Limbah Cair Pabrik Minyak Kelapa Sawit untuk Produksi Biogas. Biodiversitas 9 (1), pp. 48-52.

[16] Prasetia, H., N. Annisa., Arifin, 2016. Nilai Ekonomi, Lingkungan, dan Sosial Dari Perkebunan Sawit Swadaya di Kabupaten Seruya, Kalimantan Tengah. Jurnal Teknik Lingkungan. 2(1), pp. 71-77.

[17] Rahim, K.A., 1991. Internalisation of Externalities : Who Bears the Cost of Pollution Control?. The Environmentalist. 11(1). pp. 19-25.

[18] Rupani, P. F., R.P. Signh., M.H. Ibrahim., N. Esa, 2010. Review of Current Palm Oil Mill Effluent (POME) Treatment Methods: Vermicomposting as a Sustainable Practice. World Applied Sciences Journal. 10(10), pp. 1190-1201.

[19] Soekartawi, 1995. Analisis Usahatani.: UI-press, Jakarta.

[20] Soemirat, J., 2001. Pencemaran Lingkungan. Renika Cipta, Jakarta.

[21] Sumantri, Arif, 2010. Kesehatan Lingkungan dan Perspektif Islam. Cetakan Pertama. Kharisma Putra Utama, Jakarta.

[22] Tjay, T.H., K. Rahardja, 2007. Obat-Obat Penting Khasiat, Penggunaan, dan Efek-Efek Sampingnya. Edisi ke VI. PT Elex Media Komputindo, Jakarta.

[23] Yadav, S.S., K. Rajesh, 2011. Monitoring Water quality of Kosi River in Rampur District Uttar Pradesh, India. Advances in Applied Science Research. 2(2), pp. 197-201.

[24] Yakin, A., 1997. Ekonomi Sumberdaya dan Lingkungan. Akademika Presindo, Jakarta. 